\title{
Locomotor Activity in D2 Dopamine Receptor-Deficient Mice Is Determined by Gene Dosage, Genetic Background, and Developmental Adaptations
}

\author{
Michele A. Kelly, ${ }^{1,2}$ Marcelo Rubinstein, ${ }^{1}$ Tamara J. Phillips, ${ }^{3,5}$ Christina N. Lessov, ${ }^{3}$ Sue Burkhart-Kasch, ${ }^{3}$ \\ Ge Zhang, ${ }^{4}$ James R. Bunzow, ${ }^{4}$ Yuan Fang, ${ }^{4}$ Gregory A. Gerhardt, ${ }^{6}$ David K. Grandy, ${ }^{4}$ and Malcolm J. Low ${ }^{1}$ \\ Oregon Health Sciences University, ${ }^{1}$ Vollum Institute, Departments of ${ }^{2}$ Cell and Developmental Biology, ${ }^{3}$ Behavioral \\ Neuroscience, and 4 Physiology and Pharmacology, Portland, Oregon 97201, 5 Veterans Affairs Medical Center, Portland, \\ Oregon 97201, and 'Department of Psychiatry, University of Colorado Health Sciences Center, Denver, Colorado 80262
}

Locomotor activity is a polygenic trait that varies widely among inbred strains of mice (Flint et al., 1995). To characterize the role of $\mathrm{D} 2$ dopamine receptors in locomotion, we generated $\mathrm{F}_{2}$ hybrid (129/Sv $\times$ C57BL/6) D2 dopamine receptor (D2R)deficient mice by gene targeting and investigated the contribution of genetic background to open-field activity and rotarod performance. Horizontal activity of D2R-/- mice was approximately half that of drug-naive, strain-matched controls but was significantly greater than haloperidol-treated controls, which were markedly hypokinetic. Wild-type 129/SvEv and C57BL/6 mice with functional D2 receptors had greater interstrain differences in spontaneous activity than those among the $F_{2}$ hybrid mutants. Incipient congenic strains of D2R-deficient mice demonstrated an orderly gene dosage reduction in locomotion superimposed on both extremes of parental background locomotor activity. In contrast, $\mathrm{F}_{2}$ hybrid $\mathrm{D} 2 \mathrm{R}-/-$ mice had impaired motor coordination on the rotarod that was corrected in the congenic C57BL/6 background. Wild-type 129/SvEv mice had the poorest rotarod ability of all groups tested, suggesting that linked substrain 129 alleles, not the absence of D2 receptors per se, were largely responsible for the reduced function of the $\mathrm{F}_{2}$ hybrid $\mathrm{D} 2 \mathrm{R}-/-$ and $\mathrm{D} 2 \mathrm{R}+/-$ mice. Neurochemical and pharmacological studies revealed unexpectedly normal tissue striatal monoamine levels and no evidence for supersensitive D1, D3, or D4 dopamine receptors in the D2R-/- mice. However, after acute monoamine depletion, akinetic D2R+/- mice had a significantly greater synergistic restoration of locomotion in response to SKF38393 and quinpirole compared with any group of $\mathrm{D} 2 \mathrm{R}+/+$ controls. We conclude that D2R-deficient mice are not a model of Parkinson's disease. Our studies highlight the interaction of multiple genetic factors in the analysis of complex behaviors in gene knock-out mice.

Key words: D2 dopamine receptor; genetics; locomotor activity; C57BL/6 mice; 129/SvEv mice; dopamine; rotarod; gene knock-out mice
Locomotor activity requires the coordinated actions of cortical and subcortical structures (for review, see Hikosaka 1991; Graybiel 1991; Mink and Thatch, 1993). The basal ganglia, composed of corpus striatum, globus pallidus, subthalamic nucleus, and substantia nigra (SN), play an important role in modulating the final output of cortical motor neurons. The SN pars compacta is the major source of ascending dopaminergic input to the dorsal striatum. Striatal GABAergic neurons express dopamine receptors that belong to either the family of D1-like receptors (D1 and D1B) linked positively to adenylyl cyclase or to the D2-like receptors (D2, D3, and D4) that are inhibitory to adenylyl cyclase or coupled to G-protein-activated ion channels (Civelli et al.,

Received Nov. 25, 1997; revised Feb. 13, 1998; accepted Feb. 19, 1998.

This work was supported by Public Health Service Grants DA07262 (M.A.K.), NS09199 (G.A.G.), AG06434 (G.A.G.), and DA09620 (D.K.G.), the Department of Veterans Affairs (T.J.P.), Parke Davis Pharmaceuticals (M.J.L.), and the Lucille P. Markey Charitable Trust (M.J.L. and D.K.G.). We thank O. Rønnekleiv for assistance with D1 ligand autoradiography, E. Johnston for help with behavioral studies, S. D. Dickinson for statistical analyses, and M. Geyer and N. Zahniser for critical reading of this manuscript.

Correspondence should be addressed to Dr. Malcolm J. Low, Vollum Institute, L474, Oregon Health Sciences University, 3181 Southwest Sam Jackson Park Road, Portland, OR 97201.

Dr. Rubinstein's present address: Instituto de Investigaciones en Ingeneria Genetica y Biologia Molecular, Consejo Nacional de Investigaciones Científicas y Técnicas, University of Buenos Aires, Argentina.

Copyright (C) 1998 Society for Neuroscience $\quad 0270-6474 / 98 / 183470-10 \$ 05.00 / 0$
1993; Gingrich and Caron; 1993, Sibley et al., 1993). Although in situ hybridization studies indicated that largely segregated populations of medium spiny neurons express the D1 and D2 receptors (Graybiel, 1991; Le Moine and Bloch, 1995), more recent work using mRNA amplified from single cells demonstrated a high degree of overlap between D1- and D2-like receptors (Surmeier et al., 1996).

Despite the differences in signal transduction mechanisms, the contribution of D1- and D2-like receptors to locomotion through the direct and indirect striatopallidal projections is generally considered synergistic. Hypokinesia or akinesia can be induced pharmacologically in the mouse by antagonists of either the D1-like (Rubinstein et al., 1988; Cabib et al., 1991) or D2-like receptors (Fujiwara, 1992). However, none of the available drugs has complete specificity for any of the five known dopamine receptor subtypes. Administration of D2 antisense oligodeoxynucleotides to rats (Zhang and Creese, 1993) or mice (Zhou et al., 1994) caused only a partial reduction in striatal D2 receptors but reduced spontaneous locomotor activity. Acute monoamine depletion studies have demonstrated that stimulation of both D1- and D2-like receptors is necessary for significant reversal of the resulting akinesia (Jackson and Hashizume, 1986; Starr et al., 1987; Rubinstein et al., 1988; Zarrindast and Eliassi 1991; Ferré et al., 1994). In contrast, selective functional loss of the dopamine D1 receptor by gene targeting was reported to cause 
either an increase in baseline activity (Xu et al., 1994) or no alteration in locomotion (Drago et al., 1994). Much less is known about the contribution of the remaining dopamine receptor subtypes to locomotion or their capacity to compensate functionally for the more abundant D1 and D2 receptors, although gene deletion studies (Accili et al., 1996; Xu et al., 1997) and experiments using D3-preferring antagonists (Svensson et al., 1994) indicated that the D3 subtype may be predominantly inhibitory. Our laboratory also inferred a predominantly inhibitory role for the D4 subtype on spontaneous locomotion from a gene deletion study (Rubinstein et al., 1997).

To investigate the selective physiological role of the D2 dopamine receptor in locomotor activity, we have produced mice that lack functional D2 receptors by gene targeting in embryonic stem cells (Kelly et al., 1997). The following questions were addressed in the present study. What are the specific components of locomotion that are altered by the absence of D2 receptors? What is the contribution of gene dosage at the D2 receptor locus to locomotion? What is the interaction of the null mutation at the D2 gene locus and genetic background on locomotion? Are there identifiable adaptations in other molecular components of the nigrostriatal dopaminergic circuits in mice lacking D2 receptors? Our results from a combination of behavioral, neurochemical, and pharmacological assays emphasize the critical contribution of genetic background to analysis of a complex phenotype in the gene-targeted mice.

\section{MATERIALS AND METHODS}

\section{D2 receptor-deficient mouse strains}

The original $\mathrm{F}_{2}$ hybrid strain $(129 / \mathrm{Sv} \times \mathrm{C} 57 \mathrm{BL} / 6 \mathrm{~J})$ containing the mutated D2 receptor allele was generated in our laboratory as described previously (Kelly et al., 1997). To establish an incipient congenic B6 strain, D2 dopamine receptor $(\mathrm{D} 2 \mathrm{R})+/-$ mice were backcrossed to wild-type C57BL/6J for five generations. The sex of the $+/-$ mice was alternated between male and female for each successive generation. After the fifth generation backcross, the colony was expanded by inbreeding pairs of nonsibling $+/-$ male and female mice (all parents were $\mathrm{N}_{5}$, making all pups $\mathrm{N}_{5}$ equivalents), and each mouse was genotyped by Southern blot as described (Kelly et al., 1997). The 129/Sv strain mice that the D3 embryonic stem (ES) cells (Doetschman et al., 1985) were derived from are no longer commercially available. Therefore, to establish a substrain 129 line of mutant mice, the original male chimeras derived from the gene-targeted ES cells were bred to closely related wild-type 129/SvEvTac females (Simpson et al., 1997) to produce substrain $129+/-$ mice. The colony was then expanded as above. For simplicity these lines of mutant mice are referred to as congenic B6 and congenic 129 in this report. Wild-type C57BL/6J mice were obtained from The Jackson Laboratory (Bar Harbor, ME), and 129/SvEvTac mice were obtained from Taconic (Germantown, NY). Mice were fed on the floors of the cages to assure easy access to food. Approximately equal numbers of mice of both sexes were used for all experiments, and the data collapsed across gender if the statistical analyses revealed no gender interaction within a particular measurement.

\section{Assessment of postnatal development}

$\mathrm{F}_{2}$ hybrid +/- mice were bred, and the resultant pups were assessed from birth through postnatal day 20 when they were weaned. Physical measurements were recorded daily, including weight, eye opening, and pinnae opening. The righting reflex was assessed by placing each pup on its back and timing the return to the upright position. The ages at which each pup was first observed to perform a variety of locomotor skills, including crawling, walking, rearing, and running, were also recorded. Video recordings of these same mice both as young pups and as adults were made.

\section{Neurochemical assays}

D1 receptor saturation binding was performed on striatal membranes (30-50 $\mu \mathrm{g}$ of protein) using the D1-selective antagonist $\left[{ }^{3} \mathrm{H}\right] \mathrm{SCH} 23390$ (specific activity, $81.4 \mathrm{Ci} / \mathrm{mmol}$; DuPont NEN, Boston, MA) as a radioligand (Zhou et al., 1990) by methods described previously (Bunzow et al., 1995; Zhang et al., 1996). The saturation data were analyzed through a nonlinear regression fit of a hyperbolic equation using Graph Pad (San Diego, CA) InPlot software.

D1 receptor autoradiography was performed on $15 \mu \mathrm{m}$ cryostat brain sections using $1 \mathrm{nM}\left[{ }^{3} \mathrm{H}\right] \mathrm{SCH} 23390$ in the presence of $100 \mathrm{~nm}$ ketanserin to block 5-HT2 receptor binding, as described in previous reports (Mansour et al., 1990; Janowsky et al., 1992; LaHoste and Marshall, 1992). Nonspecific binding was demonstrated on a separate set of slides by the addition of $5 \mu \mathrm{M}(+)$-butaclamol, a nonselective dopamine receptor ligand.

Monoamines and their metabolites were determined using the methods described previously by Hall et al. (1989). All tissue levels of these compounds were determined as nanograms per gram wet weight of tissue.

\section{Measurement of locomotor activity}

Omnitech Digiscan (Columbus, OH) model CCDIGI activity monitors were used to quantify horizontal activity and rearing. All experiments were performed between 8:00 A.M. and 4:30 P.M. using animals maintained on a $12 \mathrm{hr}$ light/dark cycle from 6:00 A.M. to 6:00 P.M. The $40 \times$ $40 \mathrm{~cm}$ open-field chambers were enclosed in soundproof boxes that were in turn enclosed in a quiet room separated from the colony area. Horizontal distance was measured by the sequential breaking of infrared beams, $5 \mathrm{~cm}$ on center, in the horizontal plane of the $x$ - and $y$-axes. Initiation of movement was incremented each time a break in ambulatory activity occurred for $>1 \mathrm{sec}$. Movement time was incremented when a mouse was active for $>1 \mathrm{sec}$. The average speed of movement was obtained by dividing total horizontal distance by total time in motion for each mouse in the $30 \mathrm{~min}$ testing period. Rearing movements were counted each time an animal passed above and then below the level of a sensor in the $z$-axis vertical plane (the mouse must have remained below the level of a sensor for at least $1 \mathrm{sec}$ before it could score again).

\section{Pharmacological experiments}

Experiment 1. Mice were injected with either saline or 0.3 or $0.6 \mathrm{mg} / \mathrm{kg}$ haloperidol (McNeil Pharmaceutical Co., Fort Washington, PA), placed in a holding cage for $15 \mathrm{~min}$, and then tested in the open-field apparatus for $30 \mathrm{~min}$. All drug treatments in experiments 1 and 2 were administered intraperitoneally in a volume of $10 \mathrm{ml} / \mathrm{kg}$.

Experiment 2. Drug-naive mice were pretested in an open-field chamber for $15 \mathrm{~min}$ the day before the experiment to habituate them to the apparatus. The day of the experiment, mice were retested for $30 \mathrm{~min}$ to ascertain their pretreatment activity levels. All animals were then depleted of monoamines by treatment with $200 \mathrm{mg} / \mathrm{kg} \alpha$-methyl- $(d l)-p$ tyrosine methyl ester (AMPT) (Sigma, St. Louis, MO) followed $1 \mathrm{hr}$ later by $5 \mathrm{mg} / \mathrm{kg}$ reserpine (Sigma). One hour after reserpine treatment animals received a second lower dose of $100 \mathrm{mg} / \mathrm{kg}$ AMPT. Similar regimens have been documented to precipitously drop dopamine, norepinephrine, and to a lesser extent, 5-HT levels (Starr et al., 1987). A total of $3 \mathrm{hr}$ after the first AMPT dose, animals were tested in the open field for $30 \mathrm{~min}$ to determine their monoamine-depleted activity levels. Mice were then divided within genotype into three groups: saline, 6 $\mathrm{mg} / \mathrm{kg}$ SKF38393, or $12 \mathrm{mg} / \mathrm{kg}$ SKF38393 (Research Biochemicals, Natick, MA) and received this dose immediately before being placed in the open field for $1 \mathrm{hr}$. After this $1 \mathrm{hr}$ drug-treated trial, each group was retreated with its original dosage of SKF38393 and the addition of 2 $\mathrm{mg} / \mathrm{kg}$ quinpirole (Research Biochemicals), except the saline group, which again received saline. The animals were immediately returned to the open field for a final $1 \mathrm{hr}$ monitoring period and then killed by inhalation of $\mathrm{CO}_{2}$. Four mice were dropped from the study (depletion failures) because they scored $>20 \%$ of their premonoamine depletion distance and were $>2$ SD from the mean percentage scored by their respective group. These four mice consisted of one each $\mathrm{F}_{2}+/-, \mathrm{F}_{2}-/-$, and wild-type parental strains.

\section{Rotarod test}

Animals were placed in a neutral position on a stationary 6-cm-diameter cylinder. After $3 \mathrm{sec}$ the rotarod was switched on to a speed of $4 \mathrm{rpm}$, and the mice were timed until they fell from the rotarod (or a maximum cutoff time of $120 \mathrm{sec}$ ). Mice that attained a score of $120 \mathrm{sec}$ were removed from the rotarod and returned to their home cages; mice that fell were restarted for a total of three consecutive trials per day for $4 \mathrm{~d}$. Mice that could not remain on the stationary cylinder for three trials 
scored zero. The highest of the individual scores of each animal on each day were used for analysis.

\section{RESULTS}

\section{D2 receptor-deficient mice achieved age-appropriate developmental milestones}

All three genotypes of mice on the $\mathrm{F}_{2}$ hybrid background grew normally from birth, with no differences in birth weights and postnatal development, assessed by the timing of eye opening or pinnae opening. Additionally, there were no differences among the three genotypes in their age of acquisition of basic motor skills including the righting reflex, walking, running, rearing, and grasping before weaning (data not shown). The mice had no tremor or ataxia and did not display an abnormal stance or posture when assessed directly in an open-field test or when the same test was reviewed on videotape by observers blind to genotype (data not shown).

\section{D2 receptor-deficient mice had decreased initiation of spontaneous movement}

Preliminary experiments demonstrated that both adult $\mathrm{F}_{2}-/-$ mice and wild-type $129 / \mathrm{SvEv}$ mice displayed impaired motor function relative to wild-type C57BL/6 mice. Consequently, we performed a comprehensive analysis of spontaneous locomotor activity in an open-field on groups of drug-naive mice representing both parental strains as well as the three D2 receptor genotypes of $\mathrm{F}_{2}$ hybrid $(129 / \mathrm{Sv} \times \mathrm{C} 57 \mathrm{BL} / 6)$ mice. Independent measures included total horizontal distance traveled, number of initiations of movement, total time spent in motion, and number of rearing events. The mice ranked in order for total horizontal distance from high to low: C57BL/6, $\mathrm{F}_{2}+/+, \mathrm{F}_{2}+/-, \mathrm{F}_{2}-/-$, and $129 / \mathrm{SvEv}$ (Fig. 1A). The individual scores for each mouse were plotted on a frequency histogram and showed five discreet populations with normal distributions and a nearly complete lack of overlap between the parental strains (Fig. $1 B$ ). Within each group of mice there was a similar temporal pattern of habituation to the novel environment of the open-field as demonstrated by higher activity counts in the first time blocks compared with the later blocks (Fig. 1C). A statistical analysis demonstrated significant differences by genotype or parental strain in several measures. ANOVA $\left(F_{(4,175)}>34 ; p<0.0001\right)$ followed by Tukey post hoc tests revealed that horizontal distance, initiation of movement, time in motion (data not shown), and number of rearing events (data not shown) were lower in $\mathrm{F}_{2}-/-$ mice and wild-type 129/ SvEv mice compared with $\mathrm{F}_{2}+/+$ and wild-type C57BL/6 mice ( $p<0.0001$ for each comparison). $\mathrm{F}_{2}+/-$ mice also had significantly lower scores in these measures than $\mathrm{F}_{2}+/+$ or wild-type C57BL/6 mice ( $p,<0.03-0.0001)$. Only wild-type C57BL/6 mice had greater speed of movement than the other groups (data not shown). The differences in horizontal distance traveled could be attributed mostly to the differences in the absolute number of movement epochs initiated by each genotype or strain (Fig. 1A). An ANOVA limited to the wild-type $129 / \mathrm{SvEv}$ and $\mathrm{F}_{2}-/-$ mice demonstrated that the $\mathrm{F}_{2}-/-$ mice actually had significantly higher scores for horizontal distance $\left(F_{(1,70)}=4.75 ; p=0.03\right)$, time spent in motion $\left(F_{(1,70)}=5.47 ; p=0.02\right)$, and rearing $\left(F_{(1,70)}\right.$ $=4.39 ; p=0.04)$, but not initiation of movement.

Because there were greater differences in every measure of locomotor activity between the two wild-type parental strains than among the $F_{2}$ mice with varying numbers of $D 2$ receptors, we produced congenic 129 and B6 strains of D2 receptor-deficient mice to better assess the contribution of the single gene product

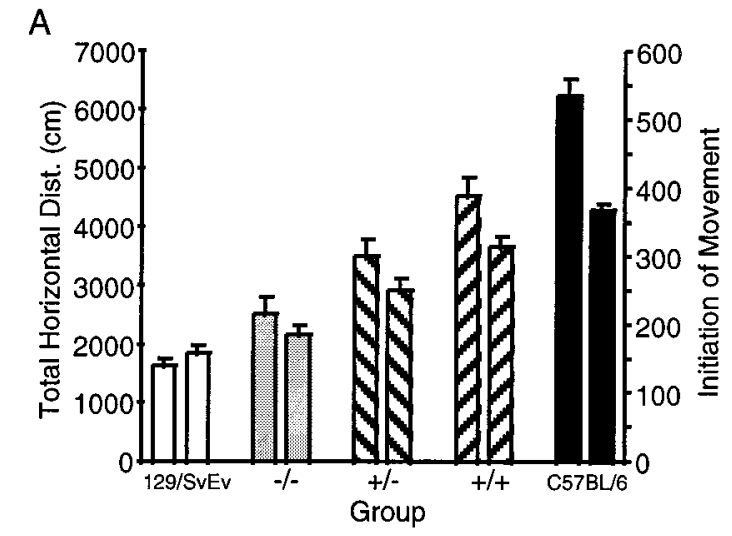

B
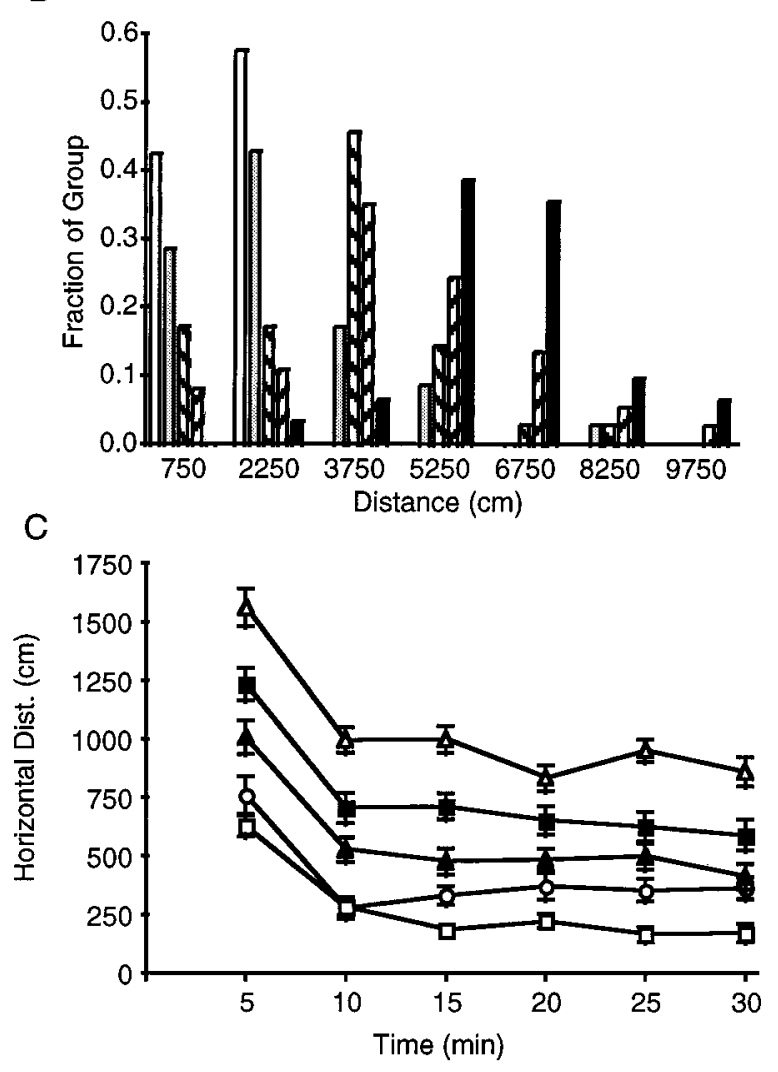

Figure 1. Locomotor activity in drug-naive $\mathrm{F}_{2}$ hybrid $\mathrm{D} 2$ receptor mutant mice and the wild-type parental strains. $A$, Total horizontal distance traveled (left) and initiation of movement (right) over $30 \mathrm{~min}$ in a novel open field. Data are mean \pm SEM. White bars, Wild-type $129 / \mathrm{SvEv}(n=35)$; gray bars, $\mathrm{F}_{2}-/-(n=36)$; diagonal right bars, $\mathrm{F}_{2}+/-(n=36)$; diagonal left bars, $\mathrm{F}_{2}+1+(n=37)$; and black bars, wild-type C57BL/6 $(n=32)$. For statistical comparisons, see Results. $B$, Frequency distribution histogram of total horizontal distance. The fraction of each group scoring within a specified range is plotted. Bin width is $1500 \mathrm{~cm}$, such that the first bin represents mice scoring from 0 to $1500 \mathrm{~cm}$ centered on $750 \mathrm{~cm}$. Groups of mice are the same as in $A$. $C$, Time course of horizontal activity in the open field during 30 min. Data are plotted as distance traveled \pm SEM in each time block of 5 min. $p<0.0001 ; \mathrm{F}_{2}-/-$ compared with $\mathrm{F}_{2}+/+$ mice, ANOVA followed by Tukey post hoc analysis. Open squares, Wild-type 129/ $\mathrm{SvEv}$; open circles, $\mathrm{F}_{2}-/-$; shaded triangles, $\mathrm{F}_{2}+/-$; shaded squares, $\mathrm{F}_{2}+/+$; open triangles, wild-type C57BL/6. 
A

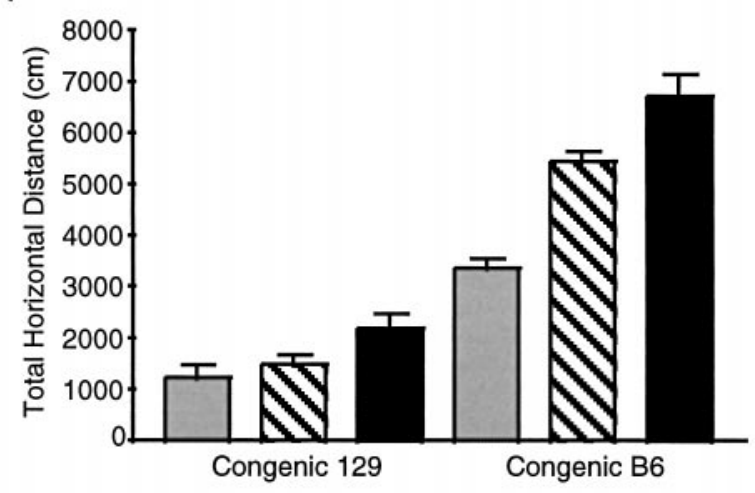

B

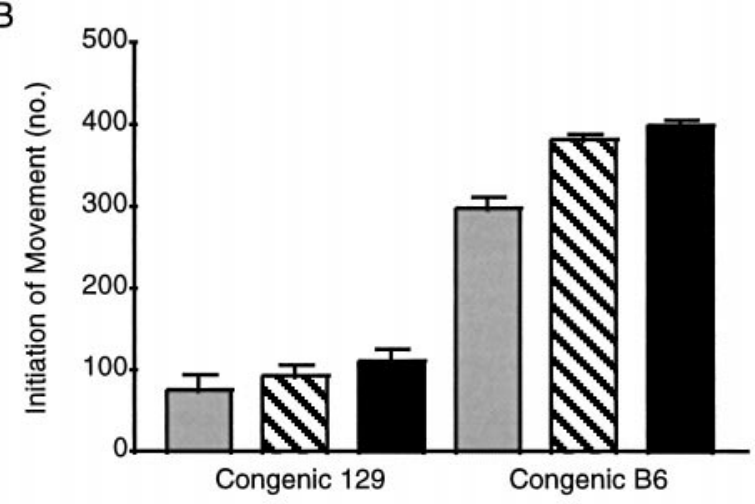

C

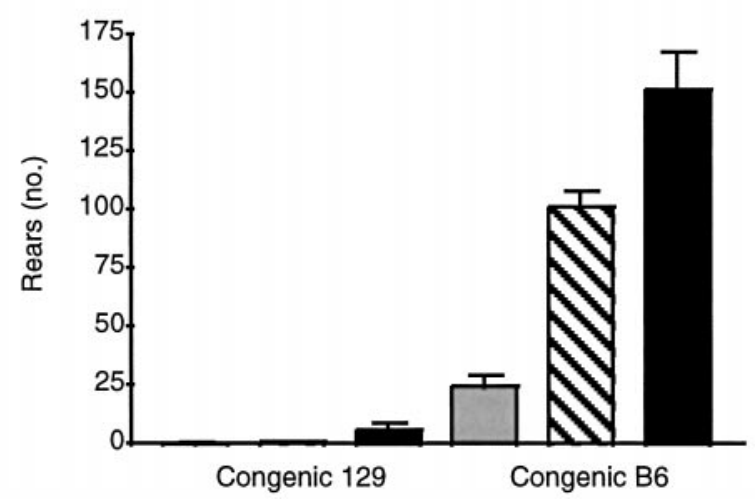

Figure 2. Locomotor activity in congenic 129 and B6 strains of D2 receptor mutant mice. $A$, Total horizontal distance traveled. $B$, Initiation of movement. $C$, Vertical rears in $30 \mathrm{~min}$ by drug-naive mice in an open field. Data are mean \pm SEM. $129-/-, n=9$ ( gray bars); $129+/-, n=20$ (striped bars); $129+/+, n=16$ (black bars); $\mathrm{B} 6-/-, n=16$ (gray bars); $\mathrm{B} 6+/-, n=36$ (striped bars); B6+/+, $n=19$ (black bars). For statistical analysis see Results.

to a polygenic complex behavior. Locomotor activity measurements for the three D2 receptor genotypes on both congenic backgrounds are shown in Figure 2. Because of the passage of time and seasonal differences in animal activity levels a direct comparison with the data in Figure 1 is not appropriate; however, the overall rank orders for total horizontal distance, rearing, and initiation of movement were clearly unchanged. The B6 congenic $-/-$ mice had significantly lower scores for total horizontal distance ( $p<0.0001$; ANOVA followed by Tukey post hoc tests), initiation of movement $(p<0.0001)$, rearing $(p<0.0001)$, and duration of horizontal movements $(p<0.0002)$ compared with their $+/+$ siblings. The B 6 congenic $+/-$ mice also demonstrated reduced total horizontal distance $(p<0.002)$ and rearing $(p<$ $0.001)$ compared with their $+/+$ siblings.

There were significant deficits in total horizontal distance $(p<$ 0.03; ANOVA followed by Tukey post hoc tests) and initiation of movement $(p<0.0013)$ in 129 congenic $-/-$ mice compared with 129 congenic $+/+$ siblings, whereas the $+/-$ mice had a significant decrease only in total horizontal distance $(p<0.05)$ when monitored in a novel open-field environment. No significant differences were found in the number of rears of the three sibling groups. For both sets of congenic mice, like the $\mathrm{F}_{2}$ mice, the D2 receptor genotype differences in total horizontal distance traveled can be attributed primarily to differences in the initiation of movement and not duration or speed of movement (data not shown).

\section{Locomotion in D2 receptor-deficient mice was not affected by haloperidol}

To further assess the involvement of the D2 receptor and contribution of genetic background to the multiple components of locomotor activity, mice of all five groups were treated acutely with $0.6 \mathrm{mg} / \mathrm{kg}$ haloperidol, a D2-like receptor antagonist. $\mathrm{F}_{2}+/-, \mathrm{F}_{2}+/+$, wild-type $129 / \mathrm{SvEv}$, and wild-type C57BL/6 mice demonstrated a drug-dependent decrease in many locomotor parameters (Table 1). In marked contrast to the other four groups, $\mathrm{F}_{2} \mathrm{D} 2 \mathrm{R}-1-$ mice treated with haloperidol were unchanged in all measured parameters. Total horizontal distance scores for all other groups of mice treated with haloperidol were actually significantly lower than the scores of $\mathrm{D} 2 \mathrm{R}-/-$ mice $(p<$ 0.0007; ANOVA followed by Tukey post hoc tests). A $0.3 \mathrm{mg} / \mathrm{kg}$ haloperidol treatment produced quantitatively smaller changes in all groups and also had no effect on the $\mathrm{F}_{2}-/-$ mice (data not shown).

The dose-dependent effects of haloperidol on locomotion in $129 / \mathrm{SvEv}$ mice suggest that the low spontaneous activity in this strain is not attributable to a coincidental absence of functional D2 dopamine receptors. $129 / \mathrm{SvEv}$ mice also had significant increases in serum prolactin secreted from the anterior pituitary gland in response to haloperidol (data not shown) and had similar $\mathrm{D} 2$ binding sites on striatal membranes compared with wild-type C57BL/6 mice measured by saturation ligand binding to $\left[{ }^{3} \mathrm{H}\right]$ nemonapride as described previously (Kelly et al., 1997). The $B_{\max }$ was $347 \pm 19$ or $303 \pm 5 \mathrm{fmol} / \mathrm{mg}$ protein, and the $K_{\mathrm{d}}$ was $44 \pm 11$ or $37 \pm 9 \mathrm{~nm}$ in $129 / \mathrm{SvEv}$ and $\mathrm{C} 57 \mathrm{BL} / 6 \mathrm{mice}$, respectively.

\section{Functional D2 receptors did not correlate with rotarod performance}

The ability to balance and walk on a rotating cylinder is a test of coordinated motor skills. Both $\mathrm{F}_{2}-/-$ mice and wild-type 129/ $\mathrm{SvEv}$ mice performed very poorly on the rotarod test with little improvement over the four consecutive days of trials (Fig. $3 A$ ). ANOVA of the mean scores by genotype on day 4 demonstrated that each of these two groups differed significantly $(p<0.05$, Tukey post hoc analysis) from $\mathrm{F}_{2}+/-, \mathrm{F}_{2}+/+$, and wild-type $\mathrm{C} 57 \mathrm{BL} / 6$ mice. However, a frequency histogram of the individual maximum scores revealed that the $\mathrm{F}_{2}+/-$ mice actually segregated into two distinct performance level populations (Fig. 3B): low performers similar to wild-type $129 / \mathrm{SvEv}$ mice and high performers similar to wild-type C57BL/6 mice. Rotarod score 


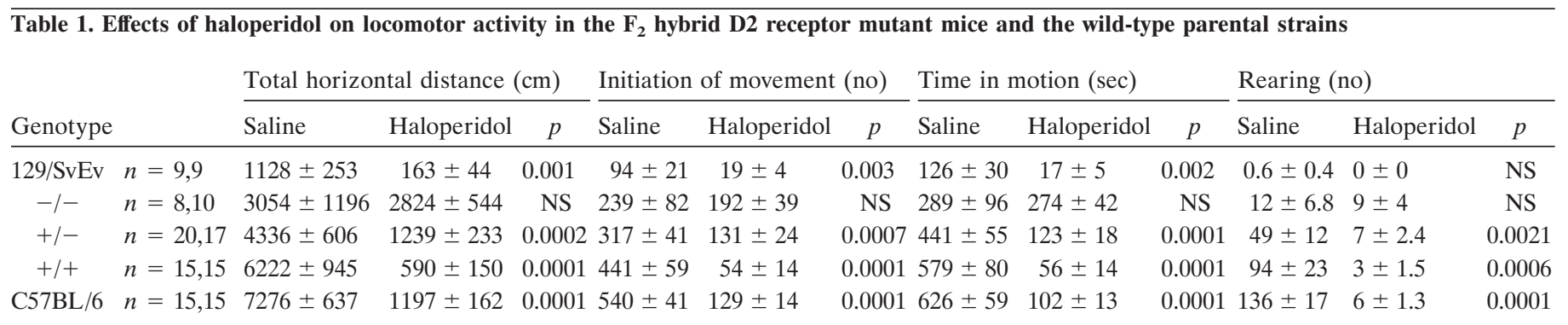

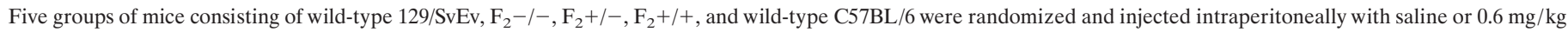

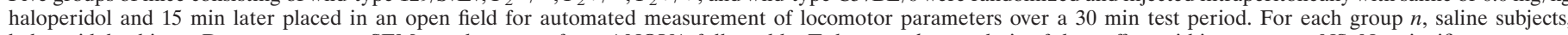
haloperidol subjects. Data are mean \pm SEM. $p$ values were from ANOVA followed by Tukey post hoc analysis of drug effect within genotype. NS, Not significant.

distributions of the other four groups of mice were all consistent with single populations.

Because it was difficult to reconcile the unexpected finding of a bimodal distribution of rotarod scores in the $\mathrm{F}_{2}+/-$ mice with the unimodal distributions of spontaneous locomotor scores and the $50 \%$ reduction in $\mathrm{D} 2$ receptor sites compared with $\mathrm{F}_{2}+/+$ mice determined by saturation ligand binding (Kelly et al., 1997) (data not shown) in the same group, we postulated that other polymorphic loci between the substrain 129 and C57BL/6 parental strains of the $\mathrm{F}_{2}$ hybrid mice might explain these data. Therefore we repeated the rotarod study using congenic B6 mice carrying the mutated D2 receptor alleles. Congenic 129 mice were not tested because of the floor effect already present in the wild-type 129/ SvEv strain on this test. The rotarod performance over $4 \mathrm{~d}$ of trials among the three genotypes of congenic B6 mice differed markedly from the $\mathrm{F}_{2}$ hybrid mice (Fig. $3 C$ ). All the congenic B6 mice had similar low scores on the first day of trials. On the second and third days the $-/-$ mice scored significantly lower ( $p<0.0001$; ANOVA followed by Tukey post hoc tests) than both $+/+$ and $+/-$ siblings. The $-/-$ mice, assessed within subjects, had improved on days 2 and 3, and by day 4 they attained final performance scores indistinguishable from both $+/+$ and $+/-$ congenic B6 siblings. Although the B6 congenic $-/-$ mice learned how to avoid falling from the rotarod with repeated trials, it was apparent from direct observation that they were never as facile at the task as their siblings with functional D2 receptors. Their qualitative behavior was also very different from that of wild-type 129/SvEv mice, which seemingly made no attempts at all of walking forward when the cylinder began to rotate.

\section{Adaptations of the nigrostriatal dopaminergic pathway in $\mathrm{D} 2$ receptor-deficient mice}

Adult mutant mice lacking D2 dopamine receptors throughout development consistently maintained $\sim 50 \%$ of the spontaneous locomotor activity of their strain-matched control siblings, moved with the same speed and duration as $+/+$ mice, and were significantly more mobile than $+/+$ mice treated acutely with a relatively D2R-selective dose of haloperidol. This degree of locomotor impairment was not obvious on casual observation of the D2R $-/-$ mice and did not impose a disability on the homozygous mutant mice in their controlled laboratory environment. Therefore we hypothesized that some compensatory mechanism was contributing to their relative normalcy.

One possibility was an increased production or turnover of dopamine in the striatum and $\mathrm{SN}$ as a result of the loss of D2 autoreceptors. The tissue content of dopamine and its metabolites, serotonin, 5-hydroxyindole-acetaldehyde, and norepinephrine were measured in the dorsal striatum (Table 2) and SN (data not shown) from congenic B6 mice of all three genotypes. Strikingly, no significant differences were found in any of these measurements in either anatomic location among genotypes.

We also characterized D1 receptor binding-sites in dorsal striatum from the mutant mice by saturation ligand binding (Fig. 4). These data demonstrated that there was a significant $20 \%$ decrease in $B_{\max }\left[273 \pm 5 \mathrm{vs} 345 \pm 15 \mathrm{fmol} / \mathrm{mg}\right.$ protein $\left(F_{(2,12)}=\right.$ $4.89 ; p<0.05)$ ], but no change in $K_{\mathrm{d}}(0.27 \pm 0.05$ vs $0.32 \pm 0.05$ $\mathrm{nm}$ ) between $-/-$ and $+/+$ mice, respectively. Autoradiography using $\left[{ }^{3} \mathrm{H}\right] \mathrm{SCH} 23390$ revealed no qualitative, regional differences in the distribution of D1 binding sites in the brains of D2-/mice (Fig. 5), including ventral striatum and frontal cortex.

To determine whether the locomotor compensation present in adult D2 receptor-deficient mice involved a functional supersensitivity of D1-like receptors, changes in the D3 or D4 receptors, or pathways using monoamines other than dopamine, we performed the following experiment.

\section{Reserpine and AMPT treatment produced akinesia in all mice}

Catecholamines and other monoamines were depleted from presynaptic terminals using a combination of reserpine (a monoamine secretory vesicle-depleting agent) (Hornykiewicz, 1966; Fujimiya et al., 1994) and AMPT (a selective inhibitor of tyrosine hydroxylase activity) (Rubinstein et al., 1988). All five groups of mice (wild-type $129 / \mathrm{SvEv}, \mathrm{F}_{2}-/-, \mathrm{F}_{2}+/-, \mathrm{F}_{2}+/+$, and wild-type C57BL/6) displayed significant decreases $\left(F_{(1,171)}>33 ; p<\right.$ $0.0001)$ within subjects in horizontal distance traveled compared with their pretreatment levels (Fig. 6). An ANOVA showed that the monoamine-depleted horizontal distance scores for $129 / \mathrm{SvEv}$, $\mathrm{F}_{2}-/-, \mathrm{F}_{2}+/-, \mathrm{F}_{2}+/+$ mice were significantly different from each other $\left(F_{(4,170)}=2.82 ; p=0.03\right)$. However, $\mathrm{F}_{2}-/-$ mice were only slightly more active than the C57BL/ 6 mice $(p<0.05$ by Tukey post hoc test). These data suggest that functional monoaminergic pathways are essential for the D2 receptor-deficient mice to maintain their basal level of locomotor activity.

\section{Monoamine-depleted D2-/- mice responded to a D1-like agonist}

The ability of mice lacking D2 receptors to move could be mediated solely by the remaining D1 receptors. To address this question we attempted to reverse the monoamine depletioninduced akinesia with SKF38393, a D1-like selective receptor agonist (Setler et al., 1978). Mice were injected with either saline or 6 or $12 \mathrm{mg} / \mathrm{kg} \mathrm{SKF} 38393$ and then placed immediately in the open-field apparatus for $1 \mathrm{hr}$. Analysis of the total horizontal distance traveled revealed that there was a significant genotype effect $\left(F_{(4,170)}=10.23 ; p<0.0001\right)$, with $\mathrm{D} 2 \mathrm{R}-/-$ mice scoring 
A
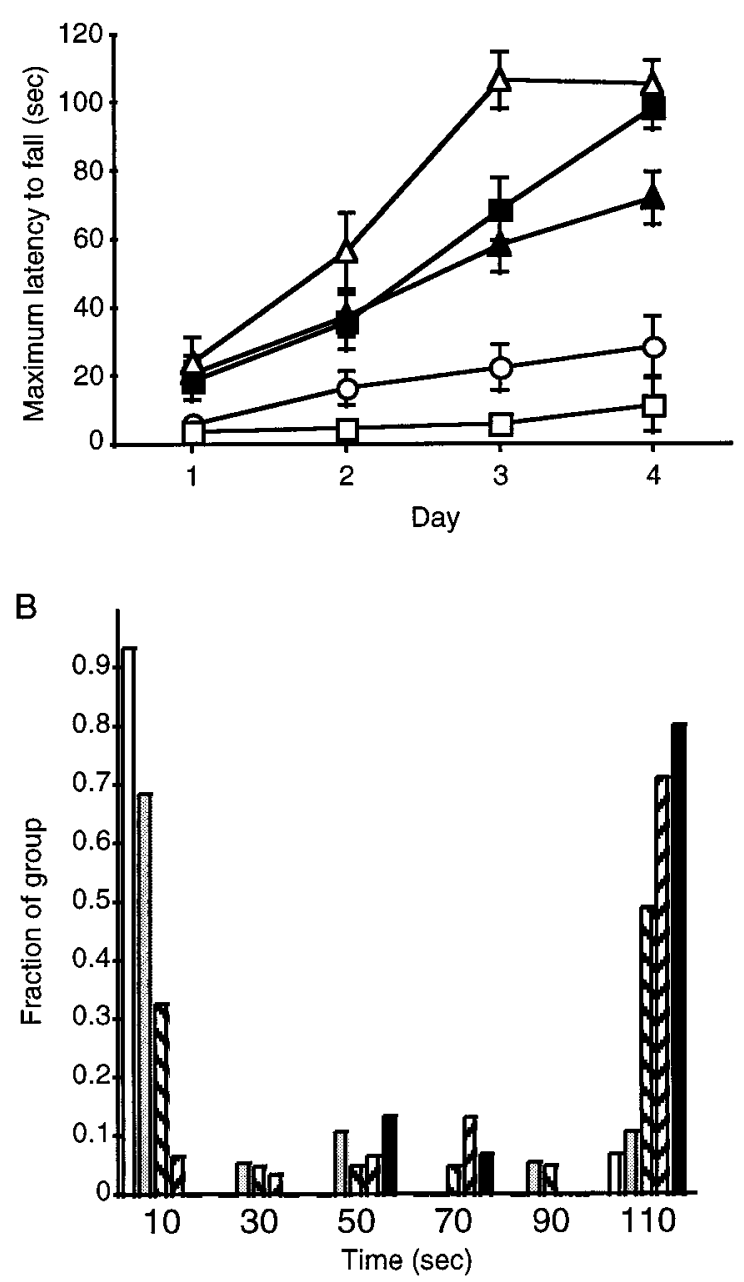

C

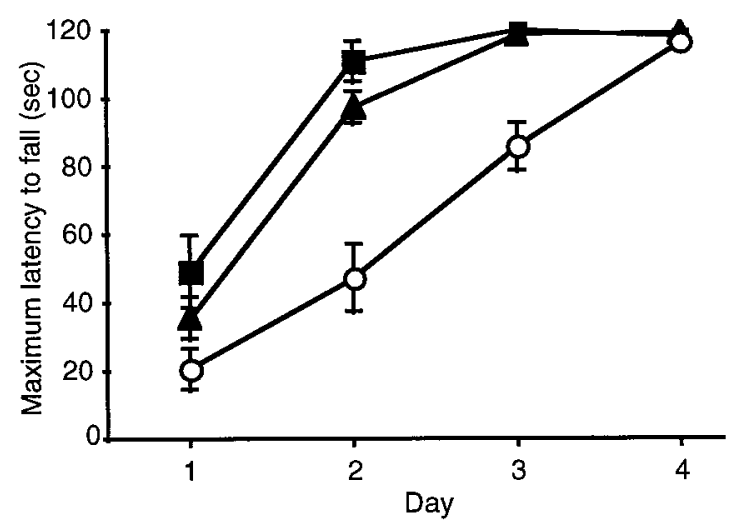

Figure 3. Rotarod testing of mutant mice and parental strains. $A$, Rotarod performance in the $\mathrm{F}_{2}$ hybrid $\mathrm{D} 2$ receptor mutant mice and the wild-type parental strains. Data are the maximal scores \pm SEM on individual test days for each group of mice. Open squares, Wild-type $129 / \mathrm{SvEv}(n=15)$; open circles, $\mathrm{F}_{2}-/-(n=18) ;$ shaded triangles, $\mathrm{F}_{2}+/-$ $(n=43)$; shaded squares, $\mathrm{F}_{2}+/+(n=31)$; open triangles, wild-type C57BL/6 $(n=15)$. $B$, Frequency distribution histogram of maximal scores on day 4 of testing in the $\mathrm{F}_{2} \mathrm{D} 2$ receptor mutant mice and the wild-type parental strains. The fraction of each group from $A$ scoring within a specified range is plotted. Bin width is $20 \mathrm{sec}$, such that the first bin represents mice scoring from 0 to $20 \mathrm{sec}$ centered on $10 \mathrm{sec}$. White bars, Wild-type $129 / \mathrm{SvEv}$; gray bars, $\mathrm{F}_{2}-/-$; diagonal right bars, $\mathrm{F}_{2}+/-$; higher than all other groups in response to SKF38393 and a treatment effect $\left(F_{(2,170)}=4.30 ; p=0.015\right)$ such that locomotor activity across genotypes was slightly stimulated by either dose of SKF38393 compared with saline administration (Fig. 6). However, there was no significant genotype by drug interaction, perhaps because of the slightly higher baseline activity in the -/mice after monoamine depletion. An analysis of covariance using the same data also failed to reveal a significantly greater response in the $\mathrm{D} 2 \mathrm{R}-/-$ mice. These findings argue against $\mathrm{D} 1$ receptor supersensitivity as the major compensatory mechanism in the D2 receptor-deficient mice.

\section{Monoamine-depleted D2-/- mice did not respond to a D2-like agonist}

Because SKF38393 alone restored only a very small portion of the original activity levels, we attempted a more complete reversal of the akinesia with a combination of SKF38393 and quinpirole, a D2-like receptor agonist (Koller et al., 1987). A preliminary experiment had shown that $2 \mathrm{mg} / \mathrm{kg}$ quinpirole alone had no stimulatory effect on the locomotion of monoamine-depleted mice (data not shown). After the initial SKF38393 or saline injection trial, the same groups of mice were treated with their original SKF38393 dosage combined with $2 \mathrm{mg} / \mathrm{kg}$ quinpirole. Mice were then returned to the open-field apparatus for a second $1 \mathrm{hr}$ period of monitoring. A comparison of the total horizontal distances scored after SKF38393 alone to the scores attained after SKF38393 and quinpirole, revealed that wild-type $129 / \mathrm{SvEv}, \mathrm{F}_{2}+/-, \mathrm{F}_{2}+/+$, and wild-type $\mathrm{C} 57 \mathrm{Bl} / 6$ mice all increased significantly $\left(F_{(1,59)}>9.36\right.$; $p<0.003)$. In contrast, the $\mathrm{F}_{2}-/-$ mice had no additional response to the combination of drugs. Unexpectedly, the $\mathrm{F}_{2}+/-$ mice scored significantly higher $(p<0.0001$ by Tukey post hoc tests) for total horizontal distance measured compared with all other groups at the lower $(6 \mathrm{mg} / \mathrm{kg})$ dose of SKF38393 plus quinpirole. A time course of the locomotor stimulatory action of the combined D1-like and D2-like agonists emphasizes the dramatic synergistic effect in the $\mathrm{F}_{2}+/-$ mice compared with all other groups (Fig. 7) and suggests that the differences in total horizontal distance shown in Figure 5 were underestimated by limiting the activity trial to $1 \mathrm{hr}$. A two-factor ANOVA comparison of saline and both doses of SKF38393 plus quinpirole revealed significant effects of genotype $\left(F_{(4,170)}=19.8 ; p<0.0001\right)$, treatment $\left(F_{(2,170)}=53.11 ; p<\right.$ $0.0001)$, and a gene $\times$ drug treatment interaction $\left(F_{(8,170)}=5.97\right.$; $p<0.0001)$. The saline groups were lower than quinpirole combined with either dose of SKF38393 ( $p<0.0001$ by Tukey post hoc test). Only mice with two functional D2 receptor alleles showed a trend toward a greater response when given the combination of the higher dose SKF38393 and quinpirole, suggesting that the +/mice had plateaued at their maximal possible response at the lower dose of SKF38393. The control groups of monoamine-depleted mice of all genotypes treated repeatedly with saline showed no spontaneous recovery, whatsoever, of locomotor activity in the course of the experiment.

diagonal left bars, $\mathrm{F}_{2}+/+$; black bars, wild-type C57BL/6. $C$, Rotarod performance in the $\mathrm{B} 6$ congenic strain of $\mathrm{D} 2$ receptor mutant mice. Data are maximal scores \pm SEM on individual test days for each group of mice. Open circles, B6-/- $(n=17) ;$ shaded triangles, B6+/- $(n=49)$; shaded squares, $\mathrm{B} 6+1+(n=20)$. B6 $-/-$ mice scored significantly lower than both other genotypes on days 2 and 3 but were indistinguishable from them by day 4 (see Results). 


\begin{tabular}{|c|c|c|c|c|c|c|c|}
\hline Genotype & $n$ & DA & DOPAC & HVA & $\mathrm{NE}$ & $5-\mathrm{HT}$ & 5-HIAA \\
\hline$-1-$ & 12 & $5688 \pm 715$ & $1441 \pm 139$ & $1989 \pm 148$ & $265 \pm 36$ & $333 \pm 26$ & $400 \pm 33$ \\
\hline$+1-$ & 29 & $5997 \pm 554$ & $1303 \pm 143$ & $1907 \pm 190$ & $250 \pm 25$ & $344 \pm 20$ & $343 \pm 18$ \\
\hline$+/+$ & 15 & $6612 \pm 924$ & $1596 \pm 147$ & $1908 \pm 232$ & $211 \pm 21$ & $352 \pm 35$ & $369 \pm 34$ \\
\hline
\end{tabular}

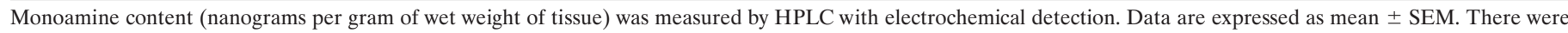
no significant differences among the three genotypes by ANOVA for each compound.

Figure 4. Saturation binding of $\left[{ }^{3} \mathrm{H}\right] \mathrm{SCH} 23390$ to striatal membranes from the B6 congenic strain of D2 receptor mutant mice. Representative data were derived from an experiment performed in duplicate, and similar results were obtained from repeated experiments. Inset, Scatchard plot of transformed saturation data.
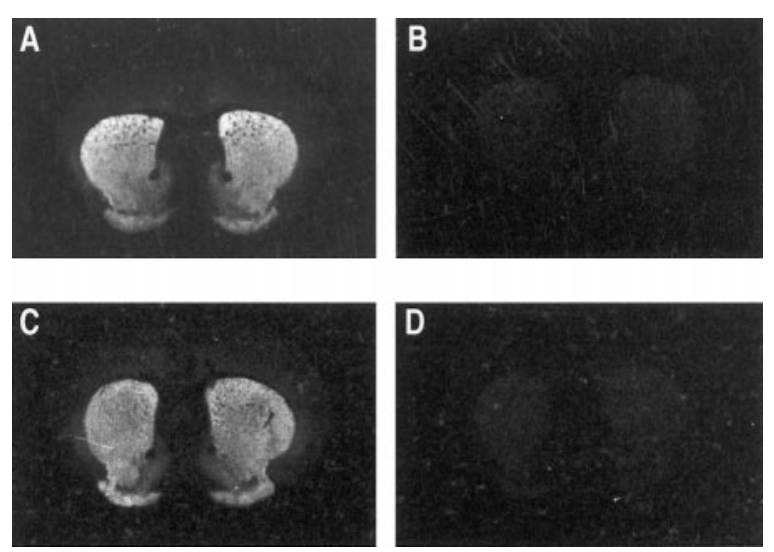

Figure 5. Autoradiographic localization of D1 receptor binding sites using $\left[{ }^{3} \mathrm{H}\right] \mathrm{SCH} 23390$. Anatomically matched sections including striatum, nucleus accumbens, and olfactory tubercle from $\mathrm{F}_{2}$ hybrid $\mathrm{D} 2$ receptor $+/+(A, B)$ and $\mathrm{F}_{2}$ hybrid $-/-(C, D)$ mice were incubated with $1 \mathrm{~nm}$ $\left[{ }^{3} \mathrm{H}\right] \mathrm{SCH} 23390$ and $100 \mathrm{~nm}$ ketanserin. Nonspecific binding was revealed by the addition of $5 \mu \mathrm{M}(+)$ butaclamol $(B, D)$.

\section{DISCUSSION}

\section{D2 receptor-deficient mice are not a model of Parkinson's disease}

Our data in the present experiments and a previous report (Kelly et al., 1997) demonstrate that we have disrupted the D2 dopamine receptor gene in the mouse and confirm a role for the D2 receptor in specific central components of locomotion: initiation of movement, time spent in motion, and horizontal distance traveled. Rearing activity was also strongly influenced by the D2 receptor. The absence of D2 receptors did not affect the speed of horizontal movement or qualitatively alter the exploratory phase of locomotor activity in a novel environment. Additionally, we observed no postural abnormalities, catalepsy, tremor, or overt ataxia in the D2 receptor-deficient mice. Therefore, other than the decreased initiation of movement, in most respects the neurological syndrome of these mice differs considerably from Parkinson's disease (Hornykiewicz, 1966); this finding is in disagreement with the interpretation of Baik et al. (1995), who analyzed an independently derived strain of $F_{2}$ hybrid D2 receptordeficient mice. It is not surprising that the presynaptic loss of dopamine found in Parkinson's disease, or pharmacologically induced by monoamine depletion, is associated with more profound neurological deficits than the absence of a single subtype of dopamine receptor.

Acute antagonism of D2 receptors by haloperidol resulted in significant decreases in the horizontal distance traveled, initiation of movement, and time spent in motion for all genotypes except the D2 receptor-deficient $-/-$ mice. Any possible antagonism of D3 (Freedman et al., 1994) and/or D4 (Asghari et al., 1995) receptors by haloperidol at the two doses used apparently had no net effect on locomotor activity in the D2R $-/-$ mice. Rearing was also significantly decreased by haloperidol, except in the D2R -/- mice and wild-type 129/SvEv mice, which exhibited virtually no basal rearing activity. 


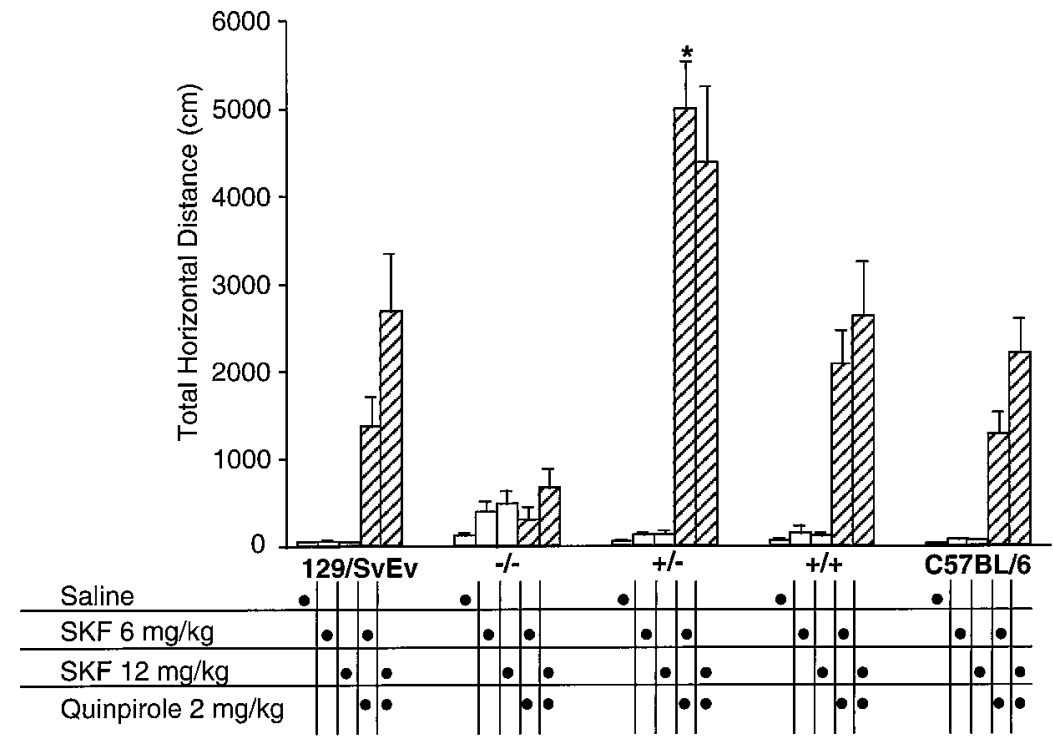

Figure 6. Reversal of monoamine depletion-induced akinesia by D1-like and D2-like agonists in the $F_{2}$ D2 receptor mutant mice and the wild-type parental strains. Groups of monoamine-depleted animals (see Materials and Methods) were treated with either saline or 6 or $12 \mathrm{mg} / \mathrm{kg}$ SKF38393 and then assessed for $60 \mathrm{~min}$ in the open field apparatus. These data are represented by the first three white bars for each group. In the next section of the experiment the same groups of mice were retreated with saline (data not shown because there was no change) or a combination of SKF38393 and $2 \mathrm{mg} / \mathrm{kg}$ quinpirole. The latter data are represented by the two striped bars for each group. All data are total horizontal distance \pm SEM; $n, 8-10$ per treatment group for each genotype or parental strain. ${ }^{*}$ Significantly higher than all other groups for this dose $(p<.0001)$.

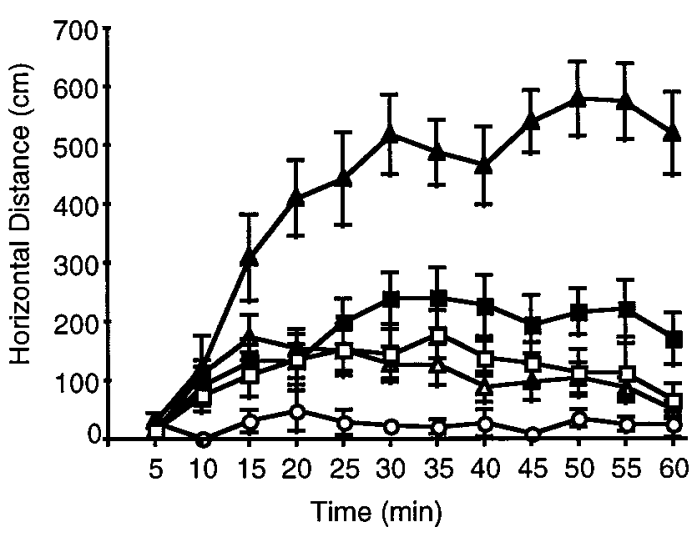

Figure 7. Time course of locomotor recovery after the combined administration of $6 \mathrm{mg} / \mathrm{kg}$ SKF38393 and $2 \mathrm{mg} / \mathrm{kg}$ quinpirole in the $F_{2}$ hybrid D2 receptor mutant mice and the wild-type parental strains. Data are plotted as mean \pm SEM of distance traveled in each time block of 5 min. Drugs were administered at time 0. Open squares, Wild-type 129/SvEv; open circles, $\mathrm{F}_{2}-1-$; shaded triangles, $\mathrm{F}_{2}+/-$; shaded squares, $\mathrm{F}_{2}+/+$; and open triangles, wild-type C57BL/6.

\section{Gene dosage effects in heterozygotes}

It is noteworthy that drug-naive and haloperidol-treated mice heterozygous for the targeted D2 allele consistently demonstrated phenotypic measures that were intermediate to those of the $+/+$ and $-/-$ mice. Scatchard analysis of $\left[{ }^{3} \mathrm{H}\right]$ nemonapride binding indicated previously that the affinity of the D2 receptor for this ligand was unchanged in $+/-$ mice, but the total number of binding sites was reduced by $\sim 50 \%$ (Kelly et al., 1997). Therefore, it does not appear that the loss of one allele and half of the receptor binding sites caused a compensatory upregulation of the remaining normal allele. If postsynaptic D2 receptors were present in excess on the cell membrane it might be predicted that $+/-$ mice with half the receptor number would have no phenotype, but this was not the case. Therefore, the decreased locomotor function displayed by $+/-$ mice in this study is consistent with a model for the nigrostriatal dopamine system that includes no spare postsynaptic D2 receptors, similar to the conclusions drawn for the abundance of D2 receptors on pituitary lactotrophs (Meller et al., 1991). The D2 receptor +/- phenotype is also in agreement with antisense knock-down experiments in which moderate reductions in D2 receptors, as assessed by ligandbinding studies, led to significant phenotypic effects (Zhang and Creese 1993; Zhou et al., 1994; Silvia et al., 1994).

The decreased $B_{\max }$ in the $+/-$ mice may be particularly relevant when considering dopamine transporter regulation, downstream second messenger effectors, and regulation of dopamine biosynthesis through dopamine D2R-like autoreceptors. We found no evidence for altered dopamine biosynthesis in either the D2+/- or $-/-$ mice based on the tissue content of dopamine and its major metabolites. However, further studies of dopamine turnover and release are warranted to more fully examine the issue of dopamine biosynthesis, particularly because recent studies provide little support for the concept of compensatory D3 autoreceptors on SN dopamine neurons (Xu et al., 1997). The unexpectedly high locomotor response of monoaminedepleted D2R+/- mice to the combined treatment by D1- and D2-like agonists further emphasizes the importance of D2 receptor gene dosage to motor function. The mechanism underlying this functional supersensitivity is unknown but probably occurs at a postreceptor level and develops in response to continued dopamine signaling through a chronically reduced number of D2 receptors. Further analyses of the heterozygous mice may prove valuable in understanding the role of D2 receptor signaling in normal brain function and plasticity at dopaminergic synapses.

\section{Importance of genetic background in gene deletion experiments}

Our study is a specific example of the importance of genetic background in the evaluation of complex behavioral traits in mice generated by targeted mutagenesis (Gerlai, 1996; Lathe, 1996; Banbury Conference on Genetic Background in Mice, 1997). The vast majority of gene knock-out experiments have used a diverse collection of ES cells derived from substrain 129 mice (Simpson et al., 1997; Threadgill et al., 1997), and the phenotypic analysis is often confined to $\mathrm{F}_{2}$ hybrid mice derived by crossing the $129 \mathrm{ES}$ cell-derived chimeras with another inbred strain, typically C57BL/6. This issue was particularly germane in the present situation, because wild-type $129 / \mathrm{SvEv}$ mice with functional D2 receptors were a virtual phenocopy of the predicted locomotor deficits caused by the loss of D2 receptors. In particular, the 
129/SvEv mice had markedly reduced scores for initiation of spontaneous movement, rearing, and rotarod performance compared with C57BL/6 mice. The low scores of the 129 parental strain produced a floor effect confounding an interpretation of the independent contribution of D2 receptors to the same measures. Therefore, a combined analysis of the parental strains and congenic strains carrying the mutated D2 receptor allele was essential to discriminate between the phenotypes resulting from either the intentional mutation in the D2 receptor gene or other polygenic loci contributed by the parental inbred strains (Flint et al., 1995).

This combined analysis revealed some surprising findings relevant to motor coordination on a rotarod. Most wild-type 129/ SvEv and $\mathrm{F}_{2}-/-$ mice were unable to perform the rotarod test after many trials, whereas wild-type C57BL/6 and congenic B6 $\mathrm{D} 2 \mathrm{R}-/-$ mice successfully learned to perform this task. Because the $\mathrm{F}_{2}-/-$ mice have undergone only a small number of meiotic crossover events on chromosome 9 (the location of the D2 receptor gene $\operatorname{Drd} 2$ in mice), it is probable that many, but not all, genes from the 129 parental chromosome 9 are still linked to the targeted D2 receptor alleles, particularly in the differential segment (Banbury Conference on Genetic Background in Mice, 1997). Consequently, it is also probable that substrain 129 gene alleles other than $\operatorname{Drd} 2$ are largely responsible for the poor rotarod performance of $\mathrm{F}_{2}-/-$ mice and the bimodal distribution of $\mathrm{F}_{2}+/-$ mice scores. The fact that the congenic B6 D2R $-/-$ mice were able to learn the rotarod task, albeit with a lower aptitude and a shallower learning curve than their siblings with intact D2 receptors, proves that the D2 receptor deficiency per se was not responsible for the failure of the $\mathrm{F}_{2}-/-$ mice on the rotarod, as concluded in a previous report (Baik et al., 1995). We believe that a differential contribution of substrain 129 gene alleles is the major reason for the apparent discrepancies in phenotypes between that report and our own. By extension of these examples, it is possible that background strain effects have influenced the interpretation of other locomotor behavioral phenotypes described for strains of mice with dopamine D1 and D3 receptor genes that have been mutated by similar techniques (Xu et al., 1994; Drago et al., 1994; Accili et al., 1996; Xu et al., 1997).

\section{Developmental adaptations in D2 receptor-deficient mice}

The net reduction in locomotor activity resulting from the chronic absence of D2 dopamine receptors in the mutant mice was significantly less than that induced by the acute pharmacological blockade of D2-like receptors by haloperidol in wild-type mice, regardless of genetic background. Therefore, we hypothesize that one or more adaptations have occurred in the CNS of the mutant mice to account for their relatively good locomotor function. D2-/- mice were still dependent on the function of monoaminergic neural circuits, because the combined blockade of dopaminergic, serotoninergic, and catecholaminergic synaptic activity with reserpine and AMPT produced akinesia. Significant reversal of akinesia was readily accomplished in both wild-type $129 / \mathrm{SvEv}$ and C57BL/6 mice by the simultaneous administration of two subtype-selective, direct dopamine agonists, SKF38393 (D1 and D1B) and quinpirole (D2, D3, and D4). Based on these observations, we predicted that dopaminergic activation of the remaining $\mathrm{D} 1, \mathrm{D} 1 \mathrm{~B}, \mathrm{D} 3$, and $\mathrm{D} 4$ receptors in $\mathrm{D} 2 \mathrm{R}-/-$ mice would be sufficient to account for their basal locomotor activity. If this prediction were true, the combination of SKF38393 and quinpirole would have reversed the reserpine-induced akinesia in D2 $-/-$ mice. In fact, the D2-/- mice demonstrated only a small response to the D1-like agonist with no additive or synergistic effect by the D2-like agonist, indicating that the primary or sole adaptation in the D2 $-/-$ mice is not the upregulation of other components of central dopaminergic circuits. There was actually a decrease in the number of D1 binding sites assessed with a radiolabeled antagonist, similar to the downregulation of D1 receptors in primate cortex, but not neostriatum, after chronic treatment with D2-like receptor antagonists (Lidow et al., 1997). An additional experiment with drug-naive mice administered 10 $\mathrm{mg} / \mathrm{kg}$ of the full D1R agonist SKF81297 also failed to demonstrate D1R-supersensitivity, although the $\mathrm{D} 2 \mathrm{R}-/-$ mice responded to the treatment with increased activity [60 min total horizontal distance scores (mean \pm SEM): saline-treated D2R-/-, $5824 \pm 1278 \mathrm{~cm}$; SKF-treated D2R-/-, 13,950 \pm 1791 $\mathrm{cm}$; saline-treated D2R+/+, $9940 \pm 682 \mathrm{~cm}$; and SKF-treated $\mathrm{D} 2 \mathrm{R}+/+, 20,730 \pm 1329 \mathrm{~cm}]$.

Further studies are necessary to fully analyze the possible contribution of nonD2 receptors and to determine the importance of serotonin, catecholamine, or other nonmonoamine neurotransmitter systems in the compensatory mechanisms. One attractive hypothesis would be a downregulation of adenosine A2A receptors that normally oppose the function of dopamine D2 receptors at common postsynaptic sites (Ferré et al., 1991; Svenningsson et al., 1997). In the future, a conditional genetargeting system for the D2 receptor will also clarify which adaptations to the absence of D2 receptors are determined by irreversible organizational plasticity in the developing brain and which occur activationally in the mature brain.

\section{REFERENCES}

Accili D, Fishbourne CS, Drago J, Steiner H, Lachowicz JE, Park BH, Gauda EB, Lee EJ, Cool MH, Sibley DR, Gerfen CR, Westphal H, Fuchs S (1996) A targeted mutation of the D3 dopamine receptor gene is associated with hyperactivity in mice. Proc Natl Acad Sci USA 93:1945-1949.

Asghari V, Sanyal S, Buchwaldt S, Paterson A, Jovanovic V, Van Tol HH (1995) Modulation of intracellular cyclic AMP levels by different human dopamine D4 receptor variants. J Neurochem 65:1157-1165.

Baik JH, Picetti R, Salardii A, Thirlet G, Dierich A, Depaulis A, Le Meur M, Borrelli E (1995) Parkinsonian-like locomotor impairment in mice lacking dopamine D2 receptors. Nature 377:424-428.

Banbury conference on genetic background in mice (1997) Mutant mice and neuroscience: recommendations concerning genetic background. Neuron 19:755-759.

Bunzow JR, Zhang G, Bouvier C, Saez C, Ronnekleiv OK, Kelly MJ, Grandy DK (1995) Characterization and distribution of a cloned rat $\mu$-opioid receptor. J Neurochem 64:14-24.

Cabib S, Castellano C, Cestari V, Filibeck U, Puglisi-Allegra S (1991) D1 and D2 receptor antagonists differently affect cocaine-induced locomotor hyperactivity in the mouse. Psychopharmacology 105: 335-339.

Civelli O, Bunzow JR, Grandy DK (1993) Molecular diversity of the dopamine receptors. Annu Rev Pharmacol Toxicol 32:281-307.

Doetschman TC, Eistetter H, Katz M, Schmidt W, Kemler R (1985) The in vitro development of blastocyst-derived embryonic stem cell lines: formation of visceral yolk sac, blood islands and myocardium. J Embryol Exp Morphol 87:27-45.

Drago J, Gerfen CR, Lachowicz JE, Steiner H, Hollon TR, Love PE, Ooi GT, Gringberg A, Lee EJ, Huang SP, Bartlett PF, Jose PA, Sibley DR, Westphal H (1994) Altered striatal function in a mutant mouse lacking D1A dopamine receptors. Proc Natl Acad Sci USA 91: $12564-12568$.

Ferré S, Herrera-Marschitz M, Grabowska-Andén M, Ungerstedt U, Casas M, Andén N-E (1991) Postsynaptic dopamine/adenosine interaction: I. adenosine analogues inhibit dopamine D2-mediated behaviour in short-term reserpinized mice. Eur J Pharmacol 192:25-30.

Ferré S, Giménez-Llort L, Artigas F, Martinez E (1994) Motor activation in short- and long-term reserpinized mice: role of N-methyl-D- 
aspartate, dopamine D1 and dopamine D2 receptors. Eur J Pharmacol 255:203-213.

Flint J, Corley R, DeFries JC, Fulker DW, Gray JA, Miller S, Collins AC (1995) A simple genetic basis for a complex psychological trait in laboratory mice. Science 269:1432-1435.

Freedman SB, Patel S, Marwood R, Emms F, Seabrook GR, Knowles MR, McAllister G (1994) Expression and pharmacological characterization of the human D3 dopamine receptor. J Pharmacol Exp Ther 268:417-426.

Fujimiya M, Okumiya K, Nakazawa M, Kitahama K, Kimura H, Maeda $\mathrm{T}$ (1994) Effect of reserpine on 5-hydroxytryptophan (5HTP)immunoreactive neurons in the rat brain. Histochemistry 101:21-26.

Fujiwara H (1992) Comparative studies of sulpiride and classical neuroleptics of catalepsy, locomotor activity, and brain dopamine metabolism in mice. Pharmacol Biochem Behav 41:301-308.

Gerlai R (1996) Gene-targeting studies of mammalian behavior: is it the mutation or the background genotype? Trends Neurosci 19:177-181.

Gingrich JA, Caron MG (1993) Recent advances in the molecular biology of dopamine receptors. Annu Rev Neurosci 16:299-321.

Graybiel AM (1991) Basal ganglia-input, neural activity, and relation to the cortex. Curr Opin Neurobiol 1:644-651.

Hall ME, Hoffer BJ, Gerhardt GA (1989) Rapid and sensitive determination of catecholamines in small tissue samples by high performance chromatography coupled with dual-electrode coulometric electrochemical detection. Liq Chromatog Gas Chromatog 7:258-265.

Hikosaka O (1991) Basal ganglia-possible role in motor coordination and learning. Curr Opin Neurobiol 1:638-644.

Hornykiewicz O (1966) Dopamine (3-hydroxytyramine) and brain function. Pharmacol Rev 18:925-964.

Jackson DM, Hashizume M (1986) Bromocriptine induces marked locomotor stimulation in dopamine-depleted mice when D-1 dopamine receptors are stimulated with SKF38393. Psychopharmacology 90:147-154.

Janowsky A, Neve KA, Kinzie M, Taylor B, de Paulis T, Belknap JK (1992) Extrastriatal dopamine D2 receptors: distribution, pharmacological characterization and region-specific regulation by clozapine. J Pharmacol Exp Ther 26:1282-1290.

Kelly MA, Rubinstein M, Asa S, Zhang G, Saez C, Bunzow JR, Allen R, Hnasko R, Ben-Jonathan N, Grandy DK, Low MJ (1997) Pituitary lactotroph hyperplasia and chronic hyperprolactinemia in dopamine D2 receptor-deficient mice. Neuron 19:103-113

Koller W, Herbster G, Anderson D, Wack R, Gordon J (1987) Quinpirole hydrochloride, a potential anti-parkinsonism drug. Neuropharmacology 26:1031-1036.

LaHoste GJ, Marshall JF (1992) Dopamine supersensitivity and D1/D2 synergism are unrelated to changes in striatal receptor density. Synapse $12: 14-26$.

Lathe R (1996) Mice, gene targeting and behaviour: more than just genetic background. Trends Neurosci 19:183-185.

Le Moine C, Bloch B (1995) D1 and D2 dopamine receptor gene expression in the rat striatum: sensitive cRNA probes demonstrate prominent segregation of D1 and D2 mRNAs in distinct neuronal populations of the dorsal and ventral striatum. J Comp Neurol 355:418-426.

Lidow MS, Elsworth JD, Goldman-Rakic PS (1997) Down-regulation of the D1 and D5 dopamine receptors in the primate prefrontal cortex by chronic treatment with antipsychotic drugs. J Pharmacol Exp Ther 281:597-603.

Mansour A, Meador-Woodruff JH, Bunzow JR, Civelli O, Akil H, Watson SJ (1990) Localization of dopamine D2 receptor mRNA and D1 and D2 receptor binding in the rat brain and pituitary: an in situ hybridization-receptor autoradiographic analysis. J Neurosci 10: 2587-2600.

Meller E, Puza T, Miller JC, Friedhoff AJ, Schweitzer JW (1991) Receptor reserve for D2 dopaminergic inhibition of prolactin release in vivo and invitro. J Pharmacol Exp Ther 257:668-674.
Mink JW, Thach WT (1993) Basal ganglia intrinsic circuits and their role in behavior. Curr Opin Neurobiol 3:950-957.

Rubinstein M, Gershanik O, Stefano FJE (1988) Different roles of D1 and D2 dopamine receptors involved in locomotor activity of supersensitive mice. Eur J Pharmacol 148:419-426.

Rubinstein M, Phillips TJ, Bunzow JR, Falzone TL, Dziewczapolski G, Zhang G, Fang Y, Larson JL, McDougal JA, Chester JA, Saez C, Pugsley TA, Gershanik O, Low MJ, and Grandy DK (1997) Mice lacking dopamine D4 receptors are supersensitive to ethanol, cocaine, and methamphetamine. Cell 90:991-1001.

Setler PE, Sarau HM, Zirkle CL, Saunders HL (1978) The central effects of a novel dopamine agonist. Eur J Pharmacol 50:419-430.

Sibley DR, Monsma FJ, Shen Y (1993) Molecular neurobiology of dopaminergic receptors. Int Rev Neurobiol 35:391-415.

Silvia CP, King GR, Lee TH, Xue ZY, Caron MG, Ellinwood EH (1994) Intranigral administration of D2 dopamine receptor antisense oligodeoxynucleotides establishes a role for nigrostriatal D2 autoreceptors in the motor actions of cocaine. Mol Pharmacol 46:51-57.

Simpson EM, Linder CC, Sargent EE, Davisson MT, Mobraaten LE, Sharp JJ (1997) Genetic variation among 129 substrains and its importance for targeted mutagenesis in mice. Nat Genet 16:19-27.

Starr BS, Starr MS, Kilpatrick IC (1987) Behavioural role of dopamine D1 receptors in the reserpine-treated mouse. Neuroscience 22:179-188.

Surmeier DJ, Song WJ, Yan Z (1996) Coordinated expression of dopamine receptors in neostriatal medium spiny neurons. J Neurosci 16:6579-6591.

Svenningsson P, LeMoine C, Kull B, Sunahara R, Bloch B, Fredholm BB (1997) Cellular expression of adenosine A2A receptor messenger RNA in the rat central nervous system with special reference to dopamine innervated areas. Neuroscience 80:1171-1185.

Svensson J, Carlsson A, Huff RM, Kling-Petersen T, Waters N (1994) Behavioral and neurochemical data suggest functional differences between dopamine D2 and D3 receptors. Eur J Pharmacol 263:235-243.

Threadgill DW, Yee D, Matin A, Nadeau JH, Magnuson T (1997) Genealogy of the 129 inbred strains: $129 / \mathrm{SvJ}$ is a contaminated inbred strain. Mamm Genome 8:390-393.

Xu M, Moratalla R, Gold LH, Hiroi N, Koob GF, Graybiel AM, Tonegawa S (1994) Dopamine D1 receptor mutant mice are deficient in striatal expression of dynorphin and in dopamine-mediated behavioral responses. Cell 79:729-742.

Xu M, Koeltzow TE, Santiago GT, Moratalla R, Cooper DC, Hu X-T, White NM, Graybiel AM, White FJ, Tonegawa S (1997) Dopamine D3 receptor mutant mice exhibit increased behavioral sensitivity to concurrent stimulation of D1 and D2 receptors. Neuron 19:837-848.

Zarrindast MR, Eliassi A (1991) Differential effects of dopamine agonists on locomotion in intact and reserpine-treated mice. Gen Pharmacol 22:1027-1031.

Zhang G, Lagrange AH, Ronnekleiv OK, Kelly MJ (1996) Tolerance of hypothalamic $\beta$-endorphin neurons to $\mu$-opioid receptor activation following chronic morphine treatment. J Pharmacol Exp Ther 277:551-558.

Zhang M, Creese I (1993) Antisense oligodeoxynucleotide reduces brain dopamine D2 receptors: behavioral correlates. Neurosci Lett 161:223-226.

Zhou LW, Zhang SP, Qin ZH, Weiss B (1994) In vivo administration of an oligodeoxynucleotide antisense to the D2 dopamine receptor messenger RNA inhibits D2 dopamine receptor-mediated behavior and the expression of D2 dopamine receptors in mouse striatum. J Pharmacol Exp Ther 268:1015-1023.

Zhou Q-Y, Grandy DK, Thambi L, Kushner JA, Van Tol HHM, Cone R, Pribnow D, Salon J, Bunzow JR, Civelli O (1990) Cloning and expression of human and rat D1 dopamine receptors. Nature 347:76-70. 